\title{
IMPACTS OF PLANTS AND SEEDS AS USED FOR DECRASING THE OBESITY IN MALE ALBINO RATS
}

\author{
By \\ Fatma El-Zahraa Amin El Ashraf Abd El-Aziz Abd \\ - Sherif \\ Prof. Dr. of Nutrition and Food \\ El - Megeid \\ Science Department, Faculty of \\ Home Economics, Minufiya \\ University \\ Sahar Abd El - Tawab Rifay Mohamed \\ Teacher in Bani Hany Preparatory School, \\ Bani Suef Governorate
}

Research Gournal Specific Fducation

Faculty of Specific Education

gYansoura University

ISSUE NO. 37, JANUARY. 2015

مجلة بعوث التربية النوعية - جامعة المنصورة

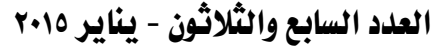




\title{
IMPACTS OF PLANTS AND SEEDS AS USED FOR DECRASING THE OBESITY IN MALE ALBINO RATS
}

\author{
Fatma El-Zahraa Amin El - Sherif* Ashraf Abd El-Aziz***
}

\section{Sahar Abd El - Tawab Rifay Mohamed ${ }^{* * *}$}

\section{Abstract}

The present work was aimed to evaluate the effect of Cinnamon bark 5 $\& 7.5 \%$, Basil seeds $5 \& 7.5 \%$, Amla seeds $5 \& 7.5 \%$, \& the mixture of all (as $5 \& 7.5 \%$ ) used as powders on obese rats. For this purpose, the study included about 60 rats, about $100-120 \mathrm{~g}$ weight ( 6 rat in each group ). Biological \& chemical analysis of serum and histopathological investigation of internal organs were carried out. The results arrived at revealed that reduction of body weight gain \% was much greater when feeding on the mixture $7.5 \%$. This group showed also maximum decrease of relative weights of liver and kidneys, which were increased pronounced by in case of control $(+)$ group. The $7.5 \%$ mixture group was the best one due to maximum decrease of serum glucose, appreciable improvements of lipids profile ( decrease of TC, TG, LDL, VLDL, AI and increase of HDL ), liver function ( reduction of GOT, GPT \& ALP ), kidneys function ( decrease of uric acid, urea and creatinine levels in serum ). Moreover, the mentioned group corrected considerably the histopathological changes.

Key wards:

Obesity, cinnamon, basil, amla, decoctions, weight gain, serum glucose, function of liver, kidneys, lipids profile, histopathological

\section{INTRODUCTION}

Obesity is a medical condition in which excess body fat has accumulated to the extent that it may have an adverse effect on health, leading to reduced life expectancy and/or increased health problems ( WHO, 2000 ). Body mass index (BMI), a measurement which compares weight

* Prof. Dr. of Nutrition and Food Science Department, Faculty of Home Economics, ** Minufiya University

${ }^{*}$ Prof. Dr. of Nutrition and Food Science Department, Faculty of Home Economics, Helwan University

Teacher in Bani Hany Preparatory School, Bani Suef Governorate 
and height, defines people as overweight (pre-obese) if their BMI is between 25 and $30 \mathrm{~kg} / \mathrm{m} 2$, and obese when it is greater than $30 \mathrm{~kg} / \mathrm{m} 2$ (Haslam and James, 2005).

Obesity increases the likelihood of various diseases, particularly heart disease, type 2 diabetes, obstructive sleep apnea, certain types of cancer, and osteoarthritis ( Haslam and James, 2005 ). Obesity is most commonly caused by a combination of excessive food energy intake, lack of physical activity, and genetic susceptibility, although a few cases are caused primarily by genes, endocrine disorders, medications or psychiatric illness. Evidence to support the view that some obese people eat little yet gain weight due to a slow metabolism is limited; on average obese people have a greater energy expenditure than their thin counterparts due to the energy required to maintain an increased body mass ( Adams and Murphy, 2000 \& Kushner, 2007 ).

Diet quality can be improved by reducing the consumption of energydense foods such as those high in fat and sugars, and may be by taking antiobesity drugs. Dietary fiber increasing may reduce appetite or inhibit fat absorption together with a suitable diet. If diet, exercise and medication are not effective, a gastric balloon may be performed to reduce surgery assist with weight loss, or stomach volume and / or bowel length, leading to earlier satiation and reduced ability to absorb nutrients from food (Imaz et al., 2008).

\section{MATERIALS AND METHODS}

\section{Materials:}

1. Casein, all vitamins, minerals, cellulose, L - Cystine and choline chloride were obtained from El - Gomhoriya Company, Cairo, Egypt.

2. Beef tallow, sucrose and corn oil were obtained from local market, Cairo, Egypt.

3. Starch was obtained from local market, Cairo, Egypt.

4. Cinnamon bark ( Cinamomum ), Amla ( Emblica officinalis ) and Basil ( Ocimum basilicum ) were obtained from the spices shop. 
5. Normal male albino rats ( 60 ) of Sprague Dawley Strain obtained from the Laboratory Animal Colony, Ministry of Health and Population, Helwan, Cairo, Egypt.

6. Kits: Kits used to determine serum total lipids ( T.L ), total cholesterol (TC), triglycerides (TG), LDL - c, HDL - c, VLDL - c, atherogenic index (AI), glucose, AST, ALT, ALP, uric acid, urea nitrogen and creatinine were obtained from Gamma Trade Company, Cairo, Egypt.

\section{Methods:}

\subsection{Preparation of decoction:}

Five grams of each plant or seed were extracted with $100 \mathrm{ml}$ of hot water for $5 \mathrm{~min}$., then left to cool. The decoctions served to rats instead of water ad - labitum

\subsection{Biological investigation:}

Male albino rats Sprague Dawley Strain ( 60 rats ) weighing ( 100 $120 \mathrm{~g}$ ) were housed in well aerated cages under hygienic condition and fed on basal diet for one week for adaptation.

The basal diet consists of $14 \%$ protein from casein ( $\geq 80 \%$ ), 5\% soya oil , $0.25 \%$ choline chloride, $1 \%$ vitamin mixture, $3.5 \%$ salt mixture, $5 \%$ cellulose, $0.18 \% \mathrm{~L}$ - cystine and the remainder $(71.07 \%)$ is corn starch ( Reeves et al ., 1993 ). The salt mixture was prepared according to Hegested et al., ( 1941 ) and the vitamin mixture was prepared according to ( Cambell, 1963 ).

\section{Biological evaluation:}

Biological evaluation of the different tested decoction was carried by determination of food intake ( FI ), weight of rats in the (initial, mid and final of the experiment ), body weight gain \% ( BWG \%) and organs weight / body weight\% according to Chapman et al., ( 1959 ) using the following equation:

$$
\text { BWG } \%=x+\frac{\text { Final weight }- \text { Initial weight }}{\text { Initial weight }}
$$


Organ weight $/$ body weight $\%=x \frac{\text { x } 100}{\text { Organ weight }}$

\section{Biochemical analysis:}

\subsection{Determination of serum lipids profile and atherogenic index:}

- Serum total cholesterol (TC) was determined according to the method described by Allain et al., (1974).

- Serum triglycerides determined according to Fossati and Principe (1982).

- HDL - c concentration ( $\mathrm{mg} / \mathrm{dl}$ ) was determined according to Burstein ( 1970 ).

- Serum LDL - c was determined according to Friedwald and Levy (1972) as follows:

LDL-c concentration $(\mathrm{mg} / \mathrm{dl})=$ Total cholesterol $-\left(+\frac{\mathrm{TG}}{\mathrm{HW}}-\mathrm{c}\right)$

- Serum VLDL - c was determined according to Friedwald and Levy ( 1972 ) as follows:

VLDL-c concentration $(\mathrm{mg} / \mathrm{dl})=\frac{\mathrm{TG}}{5}$

- Atherogenic index was calculated according to Nakabayashi et al., (1995) as follows:

Atherogenic index $(\mathrm{AI})=\frac{\mathrm{LDL}+\mathrm{VLDL}}{\mathrm{HDL}}$

- Enzymatic determination of plasma glucose was carried out according to the method of Henry (1974) and Yound (1975).

- Determination of GPT (ALT) was carried out according to Henry (1974) and Yound (1975). 
- Determination of GOT ( AST ) was carried out according to the method of Henry ( 1974 ) and Yound ( 1975 ).

- Determination of ( ALP ) was carried out according to IFCC ( 1983 ).

\subsection{Determination of kidneys functions:}

- Serum creatinine in plasma was determined calorimetrically according to the method of Bartles et al., (1972) and Larsen ( 1972 ).

- Determination of serum urea was carried according to Fawcett and Soctt ( 1960 ).

- Determination of uric acid was carried out according to Barham and Trinder ( 1972 ).

\section{Histopathological examination:}

Histopathological examination was performed according to the method of ( Carleton, 1979 ).

\section{RESULTS AND DISCUSSION}

1. Effect of feeding obese rats with Cinnamon bark, Basil \& Amla seeds on body weight gain (BWG), feed intake (FI) \& feed efficiency ratio (FER)

\section{A. Body weight gain (BWG):}

Data of table (1) show the effect of feeding obese rats with Cinnamon bark, Basil \& Amla seeds decoctions on BWG \%. It could be observed that the mean value of control (+) group was higher than that of control (-) group, being $27.446 \pm 1.288 \& 15.180 \pm 1.312 \%$ respectively. All various groups reduced the BWG \% significantly. Numerically group 10 was the best treatment for $\mathrm{BWG} \%$, showing maximum reduction.

\section{B. Feed intake ( FI ) g /day/rat:}

Data of table (1) illustrate the effect of feeding obese rats with Cinnamon bark, Basil \& Amla seeds decoctions on FI . It could be observed that the mean value of control (+) group was higher than that of control (-) group, being $14.937 \pm 1.007 \& 14.204 \pm 0.852 \%$ respectively. Numerically group 4 recorded the lowest FI . 


\section{Feed efficiency ratio( FER):}

Data of table (1) indicate the effect of feeding obese rats with Cinnamon bark, Basil \& Amla seeds decoctions on FER . It could be noticed that the mean value of control $(+)$ group was higher than that of control (-) group. being $0.137 \pm 0.005 \& 0.067 \pm 0.001$ respectively, the last group showed percent of decrease $-51.10 \%$ when compared to control( + ) group. Obese rats fed on basal diet with mixture 5\% showed nonsignificant differences as compared to control (-) group. Numerically $5 \%$ group mixture recorded the best treatment for FER.

It is evident that all diets given to obese rats corrected the elevation of BWG. Such results (Table 1) are in line with that found by El-Nagar (2010) \& Hendawy, Basma ( 2012 ) using other herbs and herbal formulations. Josh (2011) reported that Cinnamon used for weight loss in diabetic patients. Magi (2012) found that Cinnamon tea reduced the weight for people with diabetes. Kenvin (2010) found that Basil had the ability to lower cortisol levels related to stress and even help to lose weight. March (2007) reported that estragol from basil seeds is consumed before meals for weight control purpose. Anon (2010 a,b) reported that Amla (Phllanthus amarus) helps in weight loss. 


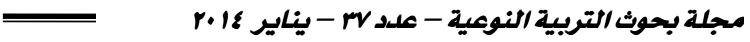

جدول بالعرض 


\section{Effect of feeding obese rats with Cinnamon bark, Basil \& Amla seeds on organs weight/ body weight $\%$}

\section{A. Liver weight / body weight \%:}

Data of table (2) illustrate the effect of feeding obese rats with Cinnamon bark, Basil \& Amla seeds on Liver weight/body weight\% . It could be observed that the mean value of control $(+)$ group was higher than that of control (-) group, being $3.287 \pm 0.215 \& 2.423 \pm 0.210 \%$ respectively. All various groups for obese rats showed significant decrease when compared to control (+) group. Basil seeds $7.5 \%$ showed nonsignificant difference when compared to healthy rats (control" -"group and recorded the best treatment for liver weight.

Table (2): Effect of Cinnamon, Basil, Amla \& their mixture on organ weight $\%$ of obese rats

\begin{tabular}{||c|c|c|c|c||}
\hline \multirow{2}{*}{ Groups } & \multicolumn{4}{|c||}{ Parameters } \\
\cline { 2 - 5 } & $\begin{array}{c}\text { Organs weight / } \\
\text { body weight } \%\end{array}$ & \% Change of & Organs weight / & \% Change of \\
& control (+) & body weight \% & control (+) group \\
& $\mathrm{M}+\mathrm{SD}$ & group & (kidney ) & \\
\hline \hline \multirow{2}{*}{ (G1) Control (-) } & $2.423 \mathrm{~d}+0.210$ & -26.29 & $0.516 \mathrm{~d}+0.051$ & -45.57 \\
(G2) Control (+) & $3.287 \mathrm{a}+0.215$ & ---- & $0.948 \mathrm{a}+0.036$ & --- \\
(G3) Cinnamon 5\% & $3.052 \mathrm{ab}+0.236$ & -7.15 & $0.727 \mathrm{~b}+0.031$ & -23.31 \\
G4) Cinnamon 7.5\% & $2.715 \mathrm{bcd}+0.462$ & -17.40 & $0.622 \mathrm{bc}+0.056$ & -34.39 \\
(G5) Basil 5\% & $2.944 \mathrm{abc}+0.294$ & -10.44 & $0.653 \mathrm{bc}+0.046$ & -31.12 \\
(G6) Basil 7.5\% & $2.544 \mathrm{~cd}+0.249$ & -22.6 & $0.677 \mathrm{bc}+0.065$ & -28.59 \\
(G7) Amla 5\% & $2.914 \mathrm{abc}+0.072$ & -11.35 & $0.642 \mathrm{bc}+0.075$ & -32.28 \\
(G8) Amla 7.5\% & $2.842 \mathrm{bc}+0.212$ & -13.54 & $0.658 \mathrm{bc}+0.053$ & -30.59 \\
(G9) Mixture 5\% & $2.967 \mathrm{ab}+0.150$ & -9.74 & $0.620 \mathrm{c}+0.082$ & -34.60 \\
(G10) Mixture 7.5\% & $2.928 \mathrm{abc}+0.262$ & -10.92 & $0.616 \mathrm{c}+0.109$ & -35.02 \\
\hline \hline
\end{tabular}

* Mean with similar latters in same row indicate nonsignificant difference and vice versa. 


\section{B. Kidneys weight/body weight $\%$ :}

Data of table indicate the effect of feeding obese rats with Cinnamon bark, Basil \& Amla seeds decoctions on kidneys weight/body weight\% . It could be noticed that the mean value of control (+) group was higher than that of control (-) group, being $0.948 \pm 0.036 \& 0.516 \pm 0.051 \%$ respectively. All various groups for obese rats showed significant decreases when compared to control (+) group. Numerically the mixture of plant \&seeds 7.5\% indicate the best treatment for kidneys weight, showing maximum decrease.

It is evident that all decoctions given to obese rats corrected the elevation of liver \& Kidney weight. Such results (Table 2) are in line with that found by El-Nagar (2010) \& El-Hindawy, Basma (2012) using other herbs and herbal formulations.

\section{Effect of feeding obese rats with Cinnamon bark, Basil \& Amla seeds on serum glucose}

Data presented in table (3) show the effect of feeding obese rats with various treatments on serum glucose $(\mathrm{mg} / \mathrm{dl})$. It could be noticed that for obese rats without treatment, the mean value of control(+)group for serum glucose was $151.250 \pm 8.220 \mathrm{mg} / \mathrm{dl}$ while in normal rats control(-)group was $83.75 \pm 3.5 \mathrm{mg} / \mathrm{dl}$. All various treatments for obese rats showed significant decreases when compared to control (+) group. The best treatment was that of $7.5 \%$ mixture diet which showed nonsignificant serum glucose difference compared to that of healthy rats. Such results (Table 3) are in line with that found by El-Nagar (2010) \& Hendawy, Basma (2012) using other herbs and herbal formulations.

Anderson et al., (2004) found that polyphenolic polymers from cinnamon may function as antioxidants, potential insulin action. Subhadra et al., (2009) reported that Cinnamon cassia extract improve fasting glucose, glucose tolerance in diabetic rats. Mohamed, Sham et al., (2011) suggested that cinnamon extract could be used as a potential nutraceutical agent for treating postprandial hyperglycemia. The same authors found that extracts 
of cinnamon which induced to diabetic rats reduce blood glucose level and it may be due to inhibition of $\alpha$-glucosidase enzyme.

Hannan et al., (2006) found that Basil ( Ocimum sanctum) leaves reduced blood glucose when adminsrtated to rats and human with diabetes. Prakash \& Gupta (2005) reported that Ocimum sanctum has also suggested to possess antidiabetic actions.

Manjunatha et al., (2001) found that Amla (Emblica offcinalis) reduced postprandial glycemia in the oral glucose tolerance test. Krishnaveni \& Mirunalini (2010) suggested that Amla fruits which has been used for traditional medicine showed antidiabetic properties. Patel et al., (2011) reported that the extract and compound isolated from Amla (Phllanthus amarus) had antidiabetic properties.

Table (3): Effect of Cinnamon, Basil, Amla \& their mixture on serum glucose of obese rats

\begin{tabular}{|c|c|c|}
\hline \multirow{2}{*}{ Groups } & \multicolumn{2}{|c|}{ Parameters } \\
\hline & $\begin{array}{c}\text { Glucose ( } \mathrm{mg} / \mathrm{dl}) \\
\mathrm{M}+\mathrm{SD}\end{array}$ & $\begin{array}{c}\% \text { Change of control (+) } \\
\text { group }\end{array}$ \\
\hline (G1) Control (-) & $38.750 g+3.500$ & -44.63 \\
\hline (G2) Control (+) & $151.250 \mathrm{a}+8.220$ & ---- \\
\hline (G3) Cinnamon 5\% & $117.250 b+4.031$ & -22.48 \\
\hline G4) Cinnamon $7.5 \%$ & $97.750 \mathrm{de}+4.272$ & -35.38 \\
\hline (G5) Basil 5\% & $106.600 c+4.082$ & -29.52 \\
\hline (G6) Basil 7.5\% & $93.750 \mathrm{ef}+2.061$ & -38.02 \\
\hline (G7) Amla 5\% & $103.000 \mathrm{~cd}+0.072$ & -31.90 \\
\hline (G8) Amla 7.5\% & $92.750 \mathrm{ef}+4.645$ & -38.68 \\
\hline (G9) Mixture 5\% & $88.500 \mathrm{fg}+5.00$ & -41.48 \\
\hline (G10) Mixture 7.5\% & $83.250 \mathrm{~g}+3.403$ & -44.95 \\
\hline
\end{tabular}

* Mean with similar latters in same row indicate nonsignificant difference and vice versa. 
4. Effect of feeding obese rats with Cinnamon bark, Basil \& Amla seeds on serum total cholesterol, triglycerides, high density lipoprotein cholesterol, low density lipoprotein cholesterol, very low density lipoprotein cholesterol $\&$ atherogenic index

\section{A. Serum total cholesterol ( T.C ) mg/dl:}

Table (4) illustrate the effect of feeding obese rats with Cinnamon bark, Basil \& Amla seeds decoctions on serum total cholesterol. It could be noticed that the mean value of control $(+)$ group was higher than that of control (-) group, being $136.750 \pm 6.946 \& 76.250 \pm 5.678 \mathrm{mg} / \mathrm{dl}$ respectively. All various treatments for obese rats showed significant decreases when compared to control (+) group. Numerically the best value of T.C was observed for rats fed on diet contained mixture of plant and seeds as $7.5 \%$.

Table (4): Effect of Cinnamon, Basil, Amla \& their mixture on serum total cholesterol \& triglycerides of obese rats

\begin{tabular}{|c|c|c|c|c||}
\hline \multirow{2}{*}{ Groups } & \multicolumn{4}{|c||}{ Parameters } \\
\cline { 2 - 5 } & $\begin{array}{c}\text { Total cholesterol (mg / } \\
\text { dl) Change } \\
\text { M }+ \text { SD }\end{array}$ & $\begin{array}{c}\text { Triglycerides (mg / } \\
\text { of control } \\
(+) \text { group }\end{array}$ & $\begin{array}{c}\text { \% Change of } \\
\text { dl) }\end{array}$ & $\begin{array}{c}\text { M }+ \text { SD } \\
\text { control (+) } \\
\text { group }\end{array}$ \\
\hline (G1) Control (-) & $76.250 \mathrm{~g}+5.678$ & -44.24 & $108.000 \mathrm{e}+4.242$ & -38.20 \\
(G2) Control (+) & $136.750 \mathrm{a}+6.946$ & ---- & $174.750 \mathrm{a}+10.563$ & --- \\
(G3) Cinnamon 5\% & $124.750 \mathrm{~b}+4.031$ & -8.78 & $151.250 \mathrm{~b}+4.349$ & -13.48 \\
G4) Cinnamon 7.5\% & $113.500 \mathrm{c}+5.686$ & -17.00 & $119.750 \mathrm{~d}+2.630$ & -31.48 \\
(G5) Basil 5\% & $110.000 \mathrm{~cd}+9.345$ & -19.56 & $146.750 \mathrm{~b}+5.377$ & -16.02 \\
(G6) Basil 7.5\% & $102.000 \mathrm{de}+7.393$ & -25.41 & $117.250 \mathrm{~d}+4.573$ & -32.90 \\
(G7) Amla 5\% & $112.000 \mathrm{~cd}+4.966$ & -18.10 & $147.250 \mathrm{~b}+5.619$ & -15.74 \\
(G8) Amla 7.5\% & $111.250 \mathrm{~cd}+10.46$ & -18.65 & $142.000 \mathrm{~b}+5.477$ & -18.74 \\
(G9) Mixture 5\% & $93.000 \mathrm{ef}+5.354$ & -31.99 & $130.250 \mathrm{c}+7.500$ & -25.46 \\
(G10) Mixture 7.5\% & $88.750 \mathrm{f}+6.994$ & -35.10 & $112.000 \mathrm{de}+6.271$ & -35.90 \\
\hline \hline
\end{tabular}

* Mean with similar latters in same row indicate nonsignificant difference and vice versa. 


\section{B. Serum triglyceride T.G ( $\mathrm{mg} / \mathrm{dl}$ ):}

Data of table (4) show the effect of feeding obese rats with Cinnamon bark , Basil \& Amla seeds decoctions on serum triglyceride (mg / dl). It could be noticed that the mean value of control (+) group was higher than that of control (-) group, being $174.750 \pm 10.563 \& 108.00 \pm 4.242 \mathrm{mg} / \mathrm{dl}$ respectively. All variables treatments for obese rats showed significant decreases when compared to control (+) group. Numerically the best value of T.G was recorded for rats fed on diet contained mixture of plant and seeds decoction $7.5 \%$.

\section{Serum high density lipoprotein cholesterol HDLc (mg/ dl):}

Data of table (5) indicated the effect of feeding obese rats with Cinnamon bark, Basil \& Amla seeds decoctions on serum HDLc ( $\mathrm{mg} / \mathrm{dl}$ ). It could be revealed that the mean value of control (+) group was lower than that of control (-) group, being 24. $500 \pm 2.081 \& 43.250 \pm 3.947 \mathrm{mg} / \mathrm{dl}$ respectively. All variables groups for obese rats showed significant decreases when compared to control (+) group. The highest increasement of HDLc was observed for rats fed on diet contained mixture of plant and seeds decoction $7.5 \%$.

Table (5): Effect of Cinnamon, Basil, Amla \& their mixture on serum high density lipoprotein cholesterol (HDLc) \& low density lipoprotein cholesterol (LDLc) of obese rats

\begin{tabular}{|c|c|c|c|c||}
\hline \multirow{2}{*}{ Groups } & \multicolumn{4}{|c||}{ Parameters } \\
\cline { 2 - 5 } & $\begin{array}{c}\text { HDLc }(\mathrm{mg} / \mathrm{dl}) \\
\mathrm{M}+\mathrm{SD}\end{array}$ & $\begin{array}{c}\text { \% Change of } \\
\text { control (+) group }\end{array}$ & $\begin{array}{c}\text { LDLc }(\mathrm{mg} / \mathrm{dl}) \\
\mathrm{M}+\mathrm{SD}\end{array}$ & $\begin{array}{c}\text { \% Change of } \\
\text { control (+) group }\end{array}$ \\
\hline \hline (G1) Control (-) & $43.250 \mathrm{a}+3.947$ & +76.53 & $11.400 \mathrm{~g}+1.608$ & -85.38 \\
(G2) Control (+) & $24.500 \mathrm{f}+2.081$ & ---- & $77.300 \mathrm{a}+4.259$ & ---- \\
(G3) Cinnamon 5\% & $27.750 \mathrm{ef}+1.707$ & +13.27 & $66.750 \mathrm{~b}+3.218$ & -13.67 \\
G4) Cinnamon 7.5\% & $33.250 \mathrm{c}+2.753$ & +35.72 & $56.300 \mathrm{c}+3.218$ & -27.17 \\
(G5) Basil 5\% & $33.500 \mathrm{~cd}+2.645$ & +36.74 & $47.150 \mathrm{de}+6.749$ & -39.00 \\
(G6) Basil 7.5\% & $35.000 \mathrm{bc}+2.160$ & +42.86 & $43.550 \mathrm{e}+5.730$ & -43.66 \\
(G7) Amla 5\% & $30.250 \mathrm{de}+1.893$ & +23.47 & $52.300 \mathrm{~cd}+3.185$ & -32.34 \\
(G8) Amla 7.5\% & $33.000 \mathrm{~cd}+3.651$ & +34.69 & $49.850 \mathrm{cde}+6.438$ & -35.51 \\
(G9) Mixture 5\% & $35.250 \mathrm{bcd}+2.362$ & +43.88 & $31.200 \mathrm{f}+4.033$ & -59.64 \\
(G10) Mixture 7.5\% & $38.000 \mathrm{~b}+3.559$ & +55.10 & $28.350 \mathrm{f}+4.685$ & -63.32 \\
\hline \hline
\end{tabular}

* Mean with similar latters in same row indicate nonsignificant difference and vice versa. 


\section{Serum low density lipoprotein cholesterol LDLc (mg / dl):}

Data of table (5) showed the effect of feeding obese rats with Cinnamon bark, Basil \& Amla seeds decoctions on serum LDLc ( $\mathrm{mg} / \mathrm{dl}$ ). It could be noticed that the mean value of control (+) group was higher than that of control (-) group, being 77. $300 \pm 4.259 \& 11.400 \pm 1.608 \mathrm{mg} / \mathrm{dl}$ respectively. All variables groups for obese rats showed significant decreases when compared to control (+) group. The highest decreasement of LDLc was found for rats fed on diet contained mixture of plant and seeds decoction $7.5 \%$.

\section{E. Serum very low density lipoprotein cholesterol VLDLc (mg / dl):}

Data of table (6) illustrate the effect of feeding obese rats with Cinnamon bark, Basil \& Amla seeds decocotions on serum VLDLc (mg / dl). It could be noticed that the mean value of control (+) group was higher than that of control (-) group, which were $34.950 \pm 2.112 \& 21.600 \pm 0.848$ $\mathrm{mg} / \mathrm{dl}$ respectively. All variables treatment for obese rats showed significant decreases when compared to control(+) group. The best decrement of VLDLc was recorded for rats fed on diet contained mixture of plant and seeds decoction $7.5 \%$.

\section{F. Serum atherogenic index ratio $\mathrm{AI}(\mathrm{mg} / \mathrm{dl})$ :}

Data of table (6) revealed the effect of feeding obese rats with Cinnamon bark, Basil \& Amla seeds decoctions on serum A.I. (mg / dl). It could be noticed that the mean value of control (+) group was higher than that of control (-) group, which were $4.607 \pm 0.297 \& 0.765 \pm 0.043 \mathrm{mg} / \mathrm{dl}$ respectively. All variable groups for obese rats showed significant decreases when compared to control (+) group. The best treatment of A.I. ratio was observed for rats fed on diet contained mixture of plant and seeds decoction $7.5 \%$.

It is evident that all diets given to obese rats corrected the elevation of serum T.C, T.G, L.D.Lc, V. L.D.Lc \& A.I. while raised H.D.L.c fraction.Such results (Tables 4,5\&6) are in line with that found by El-Nagar (2010) \& Hendawy, Basma(2012) using other herbs and herbal formulations. 
Table (6): Effect of Cinnamon, Basil, Amla \& their mixture on serum very low density lipoprotein cholesterol (VLDLc) \& atherogenic index (AI) of obese rats

\begin{tabular}{||c|c|c|c|c||}
\hline \multirow{2}{*}{ Groups } & \multicolumn{4}{|c||}{ Parameters } \\
\cline { 2 - 5 } & VLDLc (mg / dl) & \% Change of & AI (mg / dl) & \% Change of \\
& M + SD & control (+) group & M + SD & control (+) \\
& & & & group \\
\hline \hline (G1) Control (-) & $21.600 \mathrm{e}+0.848$ & -38.19 & $0.765 \mathrm{~h}+0.043$ & -83.39 \\
(G2) Control (+) & $34.950 \mathrm{a}+2.112$ & ---- & $4.607 \mathrm{a}+0.297$ & --- \\
(G3) Cinnamon 5\% & $30.250 \mathrm{~b}+0.869$ & -13.44 & $3.502 \mathrm{~b}+0.188$ & -23.98 \\
G4) Cinnamon 7.5\% & $23.950 \mathrm{~d}+0.526$ & -31.47 & $2.420 \mathrm{~d}+0.118$ & -47.47 \\
(G5) Basil 5\% & $29.350 \mathrm{~b}+1.075$ & -16.03 & $2.274 \mathrm{~d}+0.075$ & -51.22 \\
(G6) Basil 7.5\% & $23.450 \mathrm{~d}+0.914$ & -32.90 & $1.912 \mathrm{e}+0.065$ & -58.50 \\
(G7) Amla 5\% & $29.450 \mathrm{~b}+1.124$ & -15.74 & $2.705 \mathrm{c}+0.06$ & -41.29 \\
(G8) Amla 7.5\% & $28.400 \mathrm{~b}+1.095$ & -18.74 & $2.378 \mathrm{~d}+0.185$ & -48.38 \\
(G9) Mixture 5\% & $26.550 \mathrm{c}+1.454$ & -24.03 & $1.639 \mathrm{f}+0.057$ & -64.42 \\
(G10) Mixture 7.5\% & $22.400 \mathrm{de}+1.254$ & -35.91 & $1.337 \mathrm{~g}+0.045$ & -70.98 \\
\hline \hline
\end{tabular}

* Mean with similar latters in same row indicate nonsignificant difference and vice versa.

Subhadra et al., (2009) reported that Cinnamon cassia extract reduce LDLc in diabetic rats. Yu lin et al., (2011) found that oral administration of Cinnamomum osmophloeum leaves to hyperlipidemic hamsters reduced the TC, TG \& LDL levels. Alam khan et al., ( 2012 ) suggested that intake of 1, $3,6 \mathrm{gm}$ of cinnamon per day reduced serum TC,TG \& LDL in people with type 2 diabetes.

Amrani et al., (2006) suggested that Basil ( Ocimum basilicum) extract reduced TC,TG \& LDL and raised HDL of hyperlipedemic rats. Bravo et al., (2008) showed that(( Ocimum basilicum) extract used as hypocholesterolemic agent by traditional medicine in Morocco. Hicham et al., (2004) reported that (Ocimum basilicum) extract ameliorated the elevated of A.I. \& LDL/HDL ratios for hyperlipedemic mice as an expermintal model. Umar et al., (2012) concluded that the hyperlipidemia induced by high fat diet was prevented by aqueous extract of O.suava and O.basilicum. 
Manjunatha et al., (2001) found that Amla (Emblica offcinalis) reduced blood cholesterol level. Kim et al., (2005) suggested that Amla may be effective for hypercholesterolemia and prevention of atherosclerosis for cholesterol fed rats. James et al., (2009) reported that aqueous extract of Amla (Phyllanthus amarus ) reduced TC in albino rats. Gopa et al., (2012) reported that treatment of patients receiving Amla (Emblica offcinalis) produced significant reduction of TC, LDL,TG \& VLDL and significant increase in HDL levels $(\mathrm{p} \leq 0.0001)$.

5. Effect of feeding obese rats with Cinnamon bark, Basil \& Amla seeds on serum glutamic oxaloacetic transaminase GOT (AST), glutamic pyruvic transaminase GPT (ALT), alkaline phosphatase ALP \& AST/ALT ratio

\section{A. Serum glutamic oxaloacetic transaminase GOT (AST):}

Data of table (7) show the effect of feeding obese rats with Cinnamon bark, Basil \& Amla seeds decoctions on serum GOT (U/L). It could be observed that the mean value of control (+) group was higher than that of control (-) group, which were $116.500 \pm 4.123 \& 56.000 \pm 4.546 \mathrm{U} / \mathrm{L}$ respectively. All various treatment for obese rats showed significant decreases of enzyme activity when compared to control (+) group. The best treatment of AST was observed for rats fed on diet contained mixture of plant and seeds decoction $7.5 \%$.

\section{B. Serum glutamic pyruvic transaminase GPT (ALT):}

Data of table (7) indicate the effect of feeding obese rats with Cinnamon bark, Basil \& Amla seeds decoctions on serum GPT (U/L). It could be observed that the mean value of control (+) group was higher than that of control (-) group, which were $37.500 \pm 3.785 \& 22.750 \pm 2.217 \mathrm{U} / \mathrm{L}$ respectively. All variables groups for obese rats showed significant reductions of GPT activity when compared to control (+) group. Numerically the best treatment of ALT was noticed for rats fed on diet contained mixture of plant and seeds decoction $7.5 \%$. 
Table (7): Effect of Cinnamon, Basil, Amla \& their mixture on serum glutamic oxaloacetic transaminase (GOT or AST) \& glutamic pyruvate transaminase (GPT or ALT) enzymes of obese rats

\begin{tabular}{||c|c|c|c|c||}
\hline \multirow{2}{*}{ Groups } & \multicolumn{4}{|c||}{ Parameters } \\
\cline { 2 - 5 } & $\begin{array}{c}\text { GOT ( AST ) (U/L) } \\
\text { M + SD }\end{array}$ & $\begin{array}{c}\text { Change of } \\
\text { control (+) } \\
\text { group }\end{array}$ & $\begin{array}{c}\text { GPT ( ALT ) (U / L) } \\
\text { M + SD }\end{array}$ & $\begin{array}{c}\text { \% Change of } \\
\text { control (+) group }\end{array}$ \\
\hline \hline (G1) Control (-) & $56.00 f+4.546$ & -51.93 & $22.750 \mathrm{e}+2.217$ & -39.33 \\
(G2) Control (+) & $116.500 \mathrm{a}+4.123$ & ---- & $37.500 \mathrm{a}+3.785$ & ---- \\
(G3) Cinnamon 5\% & $90.225 \mathrm{~b}+4.986$ & -22.55 & $33.000 \mathrm{bc}+3.366$ & -12.00 \\
G4) Cinnamon 7.5\% & $72.600 \mathrm{cde}+3.871$ & -37.68 & $28.000 \mathrm{~d}+2.160$ & -25.33 \\
(G5) Basil 5\% & $88.500 \mathrm{~b}+9.469$ & -24.03 & $33.750 \mathrm{abc}+3.947$ & -10.00 \\
(G6) Basil 7.5\% & $74.000 \mathrm{~cd}+1.414$ & -36.48 & $31.500 \mathrm{~cd}+1.129$ & -16.00 \\
(G7) Amla 5\% & $92.750 \mathrm{~b}+7.932$ & -20.39 & $36.500 \mathrm{ab}+3.109$ & -2.67 \\
(G8) Amla 7.5\% & $78.750 \mathrm{c}+2.63$ & -32.40 & $32.500 \mathrm{bc}+2.081$ & -13.33 \\
(G9) Mixture 5\% & $69.250 \mathrm{de}+3.500$ & -40.56 & $23.690 \mathrm{e}+1.224$ & -36.83 \\
(G10) Mixture 7.5\% & $65.250 \mathrm{e}+2.500$ & -46.57 & $23.316 \mathrm{e}+0.817$ & -37.82 \\
\hline \hline
\end{tabular}

* Mean with similar latters in same row indicate nonsignificant difference and vice versa.

\section{Serum alkaline phosphatase ALP:}

Data of table (8) illustrate the effect of feeding obese rats with Cinnamon bark, Basil \& Amla seeds decoctions on serum ALP (U/L). It could be noticed that the mean value of control (+) group was higher than that of control (-) group, being $266.250 \pm 11.842 \& 128.250 \pm 10.626 \mathrm{U} / \mathrm{L}$ respectively. All various groups for obese rats showed significant decreases of activity when compared to control (+) group. Numerically the best treatment of ALT was found for rats fed on diet contained mixture of plant and seeds decoction $7.5 \%$. 
Table (8): Effect of Cinnamon, Basil, Amla \& their mixture on serum alkaline phosphatase (ALP) \& AST / ALT ratio of obese rats

\begin{tabular}{||c|c|c|c|c||}
\hline \multirow{2}{*}{ IGroups } & \multicolumn{4}{|c||}{ Parameters } \\
\cline { 2 - 6 } & $\begin{array}{c}\text { AST / ALT } \\
\text { M + SD }\end{array}$ & $\begin{array}{c}\% \text { Change of } \\
\text { control (+) } \\
\text { group }\end{array}$ & $\begin{array}{c}\text { ALP (U / L) } \\
\text { M + SD }\end{array}$ & $\begin{array}{c}\% \\
\text { Change } \\
\text { of control } \\
(+) \text { group }\end{array}$ \\
\hline \hline (G1) Control (-) & $2.464 \mathrm{de}+0.047$ & -21.15 & $128.250 \mathrm{~g}+10.626$ & -51.83 \\
(G2) Control (+) & $3.125 \mathrm{a}+0.250$ & ---- & $266.250 \mathrm{a}+11.842$ & ---- \\
(G3) Cinnamon 5\% & $2.775 \mathrm{bc}+0.170$ & -11.20 & $236.500 \mathrm{~cd}+5.322$ & -11.17 \\
G4) Cinnamon 7.5\% & $2.600 \mathrm{~cd}+0.163$ & -16.80 & $218.500 \mathrm{e}+3.109$ & -17.93 \\
(G5) Basil 5\% & $2.632 \mathrm{~cd}+0.121$ & -15.78 & $242.250 \mathrm{bc}+3.403$ & -9.01 \\
(G6) Basil 7.5\% & $2.351 \mathrm{e}+0.101$ & -24.77 & $228.750 \mathrm{~d}+1.258$ & -14.09 \\
(G7) Amla 5\% & $2.578 \mathrm{~cd}+0.118$ & -17.50 & $247.500 \mathrm{~b}+3.415$ & -7.04 \\
(G8) Amla 7.5\% & $2.426 \mathrm{de}+0.096$ & -22.37 & $235.500 \mathrm{~cd}+3.415$ & -11.55 \\
(G9) Mixture 5\% & $2.925 \mathrm{ab}+0.125$ & -6.40 & $159.00 \mathrm{f}+3.415$ & -40.28 \\
(G10) Mixture 7.5\% & $2.798 \mathrm{bc}+0.092$ & -10.46 & $151.750 \mathrm{f}+4.113$ & -43.01 \\
\hline \hline
\end{tabular}

* Mean with similar latters in same row indicate nonsignificant difference and vice versa.

\section{Serum AST/ALT ratio:}

Data of table (8) indicate the effect of feeding obese rats with Cinnamon bark, Basil \& Amla seeds decoction on serum AST / ALT (U/L). It could be observed that the mean value of control (+) group was higher than that of control (-) group, being $3.125 \pm 0.250 \& 2.464 \pm 0.047 \mathrm{U} / \mathrm{L}$ respectively. All various groups for obese rats showed significant reductions when compared to control (+) group. The best treatment of AST/ALT ratio was observed for rats fed on diet contained basil seeds $7.5 \%$, which revealed nonsignificant difference compared to olant $\&$ seed mixture decoction 7.5 $\%$.

It is evident that all diets given to obese rats corrected the elevation of serum AST,ALT, ALP\&AST/ALT ratio. Such results (Tables $7 \& 8$ ) are in line with that found by El-Nagar (2010) \& Hendawy, Basma (2012) using other herbs and herbal formulations. 
Giridhar et al., (2009) found that alcohol extract from cinnamon bark may protect the liver from acute alcohol- induced steatosis. Said \& Husein (2009) reported that cinnamon extract restored the elevation of AST\&ALT to normal level in hepatic injury rats.

Parkash \& Gupta (2005) found that Ocimum sanctum L has also been suggested to possess hepatoprotectiv action. Anon ( $2010 \mathrm{a}, \mathrm{b})$ suggested that holy Basil may be able to treat liver damage showing hepatoprotective activity. Labon \& Das ( 2011) reported that Ocimum sanctum alcoholic leafs extract shows significant hepatoprotective activity and synergism with silimarin. James et al., (2009) reported that Amla extracts reduced AST, ALT in albino rats. Krishnaveni \& Mirunalini (2010) suggested that Amla fruits which has been used for traditional medicine showed hepatoprotectiv properties. Patel et al., (2011) reported that the extract of Amla showed hepatoprotective properties.

\section{Effect of feeding obese rats with Cinnamon bark, Basil \& Amla seeds on serum uric acid, urea \& creatinine $\mathrm{mg} / \mathrm{dl}$}

\section{A. Serum uric acid $\mathrm{mg} / \mathrm{dl}$ :}

Data of table (9) show the effect of feeding obese rats with Cinnamon bark , Basil \& Amla seeds decoctions on serum uric acid ( $\mathrm{mg} / \mathrm{dl}$ ). It could be noticed that the mean value of control ( + ) group was higher than that of control (-) group, being $3.100 \pm 0.230 \& 1.525 \pm 0.095 \mathrm{mg} / \mathrm{dl}$ respectively. All various groups for obese rats showed significant decreases when compared to control(+) group. The best treatment of uric acid was found for rats fed on diet contained mixture of plant $\&$ seeds $7.5 \%$.

\section{B. Serum urea $\mathrm{mg} / \mathrm{dl}$ :}

Data of table (9) illustrate the effect of feeding obese rats with Cinnamon bark, Basil \& Amla seeds decoctions on serum urea $(\mathrm{mg} / \mathrm{dl})$. It could be observed that the mean value of control (+) group was higher than that of control (-) group, being $88.750 \pm 5.560 \& 42.250 \pm 4.573 \mathrm{mg} / \mathrm{dl}$ respectively. All various groups for obese rats showed significant reductions when compared to control(+) group. Numerically the better treatment of urea was recorded for rats fed on diet contained cinnamon $7.5 \%$, which did 
not significant difference compared to that of $7.5 \%$ plant \& seed mixture decoction.

Table (9): Effect of Cinnamon, Basil, Amla \& their mixture on urea, uric acid and creatinine of obese rats

\begin{tabular}{|c|c|c|c|c|c|c|}
\hline \multirow[t]{2}{*}{ Groups } & \multicolumn{6}{|c|}{ Parameters } \\
\hline & $\begin{array}{l}\text { Uric acid } \\
\mathrm{mg} / \mathrm{dl} \\
\mathrm{M}+\mathrm{SD}\end{array}$ & $\begin{array}{c}\% \\
\text { Change } \\
\text { of } \\
\text { control } \\
(+) \\
\end{array}$ & $\begin{array}{c}\text { Urea } \\
\mathrm{mg} / \mathrm{dl} \\
\mathrm{M}+\mathrm{SD}\end{array}$ & $\begin{array}{c}\% \\
\text { Change } \\
\text { of } \\
\text { control } \\
(+) \\
\end{array}$ & $\begin{array}{l}\text { Creatinine } \\
\mathrm{mg} / \mathrm{dl} \\
\mathrm{M}+\mathrm{SD}\end{array}$ & $\begin{array}{c}\% \\
\text { Change } \\
\text { of } \\
\text { control } \\
(+) \\
\end{array}$ \\
\hline (G1) Control (-) & $1.525 g+0.095$ & -50.81 & $42.250 \mathrm{e}+4.573$ & -52.39 & $0.525 d+0.064$ & -53.33 \\
\hline (G2) Control (+) & $3.100 a+0.230$ & ---- & $88.750 a+5.560$ & ---- & $1.125 a+0.170$ & ---- \\
\hline (G3) Cinnamon 5\% & $2.450 b c+0.173$ & -20.97 & $60.250 b+2.217$ & -32.11 & $0.875 b+0.125$ & -22.22 \\
\hline (G4) Cinnamon $7.5 \%$ & $2.200 \mathrm{cde}+0.163$ & -29.03 & $45.500 \mathrm{de}+4.041$ & -48.73 & $0.650 \mathrm{~cd}+0.129$ & -42.22 \\
\hline (G5) Basil 5\% & $2.600 b+0.115$ & -16.13 & $56.000 \mathrm{bc}+6.683$ & -36.90 & $0.850 b+0.129$ & -24.44 \\
\hline (G6) Basil 7.5\% & $2.075 \mathrm{ef}+0.206$ & -33.03 & $47.000 \mathrm{de}+2.449$ & -47.04 & $0.625 c d+0.125$ & -44.44 \\
\hline (G7) Amla 5\% & 2.375 bed +0.095 & -23.39 & $58.250 b+4.272$ & -34.37 & $0.750 b c+0.057$ & -33.33 \\
\hline (G8) Amla 7.5\% & $2.150 \mathrm{def}+0.191$ & -30.65 & $50.250 \mathrm{~cd}+5.377$ & -43.38 & $0.625 \mathrm{~cd}+0.095$ & -24.44 \\
\hline (G9) Mixture 5\% & $2.145 \mathrm{def}+0.016$ & -30.81 & $49.750 \mathrm{~cd}+2.630$ & -43.94 & $0.650 \mathrm{~cd}+0.057$ & -42.22 \\
\hline (G10) Mixture $7.5 \%$ & $1.925 f+0.150$ & -37.90 & $46.250 \mathrm{de}+1.893$ & -47.89 & $0.550 \mathrm{~d}+0.091$ & -51.11 \\
\hline
\end{tabular}

* Mean with similar latters in same row indicate nonsignificant difference and vice versa.

\section{Serum creatinine mg / dl:}

Data of table (9) indicate the effect of feeding obese rats with Cinnamon bark, Basil \& Amla seeds decoction on serum creatinine $(\mathrm{mg} / \mathrm{dl})$ . It could be noticed that the mean value of control (+) group was higher than that of control (-) group, being $1.125 \pm 0.170 \& 0.525 \pm 0.064 \mathrm{mg} / \mathrm{dl}$ respectively. All various groups for obese rats showed significant decreases when compared to control (+) group. The mixture of plant and seeds decoction $7.5 \%$ showed nonsignificant difference when compared to healthy rats (control" -"group)and recorded the best treatment for decreasing serum creatinine .

It is evident that all diets given to obese rats corrected the elevation of serum uric acid, urea $\&$ creatinine $\mathrm{mg} / \mathrm{dl}$. Such results ( Tables 9 )are in line 
with that found by El-Nagar (2010) \& Hendawy, Basma (2010) using other herbs and herbal formulations.

Chris (2011) suggested that Cinnamon have an effect on kidney health because Cinnamon improved the level of blood sugar. Anon ( 2012 a,b ) reported that Cinnamon cassia are used for kidney disorder.

Denise (2010) found that Basil leaves may help reduce the size or even eliminate the presence of kidneys stone. Anon (2009) reported that basil had strengthening effect on kidney and in case of renal stone the juice of basil leaves, if taken regularly for 6 months, will expel them via the urinary tract.

Yokozawa et al., (2007) suggested that the administration of Amla or an ethyl acetate extract of Amla reduced the elevated levels of serum creatinine and urea nitrogen in aged rats. Chen et al ., (2009), however, found that Amla extract did not influence renal function in uremic patients. Patel et al., (2011) reported that the extract and compound isolated from Amla (Phllanthus amarus) had diuretic properties.

\section{Histopathological:}

Histopathological investigation revealed the normal structure of liver and kidneys tisuuefor healthy control ( - ) group ( Photos $1 \& 2$ ). By the effect of obesity ( control "+" group ) some changes occurred ( Photos $3 \&$ 4). Meanwhile cinnamon, basil \& amla corrected the histopathological changes, in particular when using the mixture of at $7.5 \%$ ( Photos $5 \& 6$ ). 
Liver

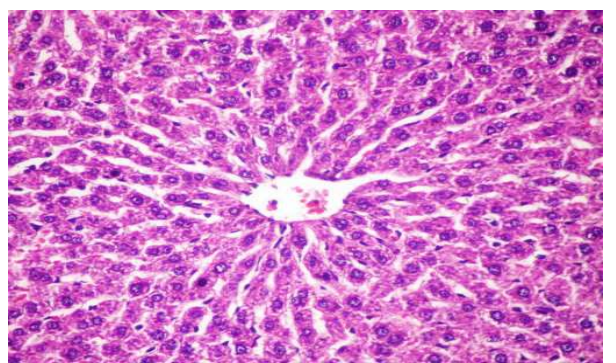

Photo (1): Liver of rat from group negative showing the normal histological structure of hepatic lobule. (H and X E 400)

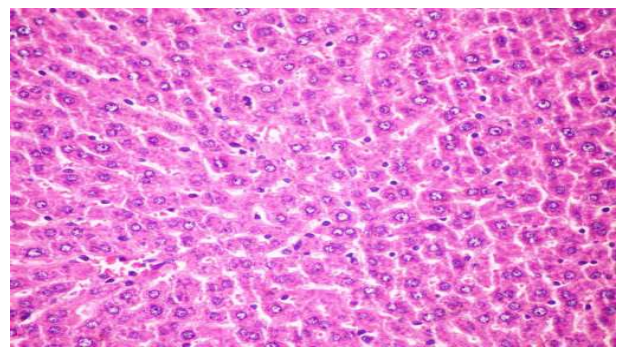

Photo (3): Liver of rat from group positive showing kupffer cells activation and necrosis of sporadic hepatocytes.

(H and X E 400)

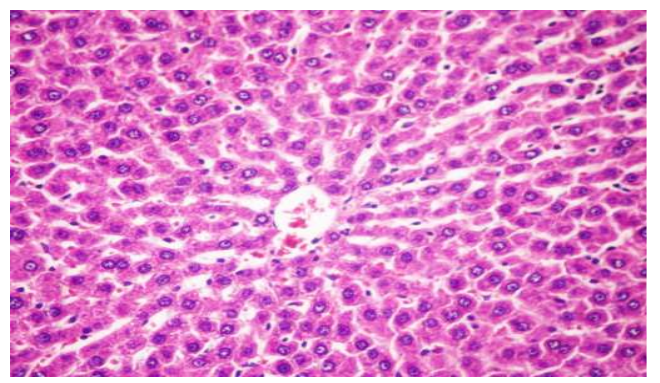

Photo (5): Liver of rat from group

Mixture $7.5 \%$ showing no histopathological changes.

(H and X E 400)

\section{Kidney}

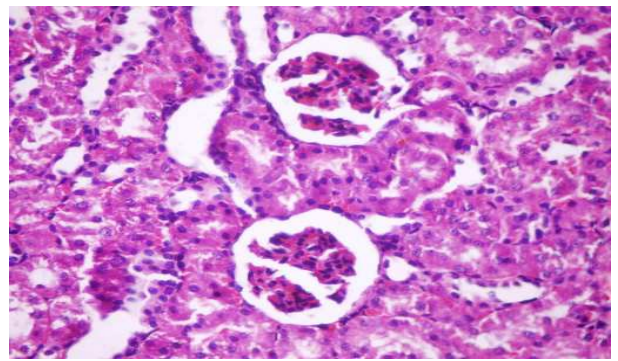

Photo (2): Kidney of rat from group negative showing the normal histological structure of renal parenchyma.

(H and X E 400)

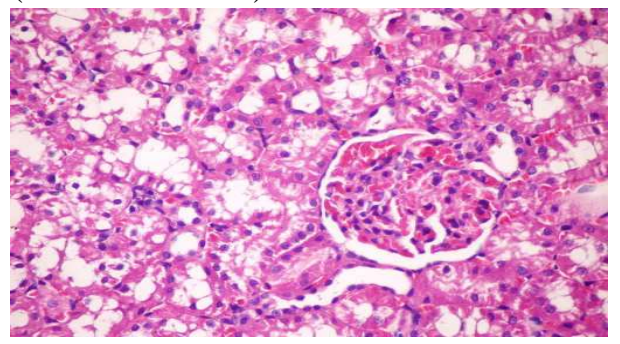

Photo (4): Kidney of rat from group positive showing congestion of glomerular tufts and vacuolations of epithelial lining renal tubules.

(H and X E 400)

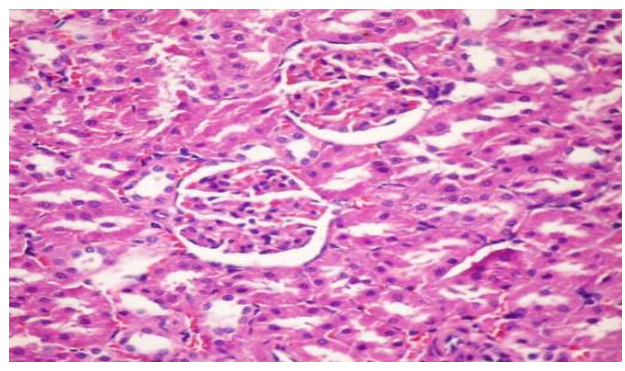

Photo (6): Kidney of rat from group Mixture $7.5 \%$ showing no histopathlogical changes.

(H and X E 400) 


\section{REFERENCES}

- Adams, J.P. and Murphy, P.G. (2000) : "Obesity in anaesthesia and intensive care". Br. J. Anaesth., 85 (1) : 91 - 108.

- Allain, C.C. (1974): "Cholesterol enzymatic colorimetric method". J. of Clin. Chem., $20: 470$.

- Amrani, S.; Harnafi, H.; Bouanani, N.H.; Aziz, M.; Caid, H.S.; Manfredini, S.; Besco, E.; Napolitano, M. and Bravo, E. (2006): "Hypolipidaemic activity of aqueous ( Ocimum basilicum ) extract in acute hyperlipidaemia induced by triton WR-1339 in rats and its antioxidant property". Phytother. Res., 20 ( 12 ) : 1040 - 5.

- Anderson, R.A.; Broadhurst, C.L.; Polansky, M.M.; Schmidt, W. F. ; Khan, A.; Flanagan, V.P.; Schoene, N.W. and Graves , D. J. (2004) : "Isolation and characterization of polyphenol type -A polymers from cinnamon with insulin-like biological activity". J. Agric. Food Chem., Jan. 14; 52 ( 1 ) : 65 - 70.

- Anon (2010 a) : http://www.fightobesity.net/17032010/cinnamon-andweight-loss-311.html.

- Anon ( 2010 b ) : http://rajanjolly.hubpages.com/hub/Amazing-HolyBasil-Yulsi-Cures.

- Barham, D. and Trinder, P. ( 1972 ): "Determination of uric acid". Analyst, 97: 142.

- Bartles, J.; Bohmer, M. and Heirli, C. (1972): "Determination of creatinine". Clin. Chem., Acta, 37 : 193.

- Bravo, E.; Amrani, S.; Aziz, M.; Harnafi, H. and Napolitano, M. (2008) : "Ocimum basilicum ethanolic extract decreases cholesterol synthesis and lipid accumulation in human macrophages" Fitoterapia, 79 ( 7-8 ) : 515 23.

- Burstein, M. ( 1970 ) : Determination of HDL-c. Lipid Res., 11 : 583.

- Campbell, J. A. ( 1963 ) : "Methodology of protien Evaluation". RGA Nut. Document R. 10 Led., 37 . June Meeting, New York.

- Carleton, H. ( 1979 ) : Histological Techniques. 4th Ed., London, Oxford, New York, Toronto.

- Chapman, D.G.; Castilla,R. and Campbell, J. A. ( 1959 ) : "Evaluation of protein in food. LA. Method for the determination of protein efficiency ratio". Can. J. Biochem. Physiol., 37 : $679-686$. 
- Chen, T.S.; Liou, S.Y. and Chang,Y.L. (2009): "Supplementation of Emblica officinalis (Amla) extract reduces oxidative stress in uremic patients". Am. J. Chin. Med., 37 ( 1 ) : $19-25$.

- El - Nagar, M.M. ( 2010 ): Effect of Some Plant Materials and Herbs as Used for Correcting Obesity of Male Albino Rats. Ph.D. Thesis, Faculty of Home Economics, Minufiya University.

- Fawcett, J.K. and Soctt, J.E. ( 1960 ) : "Determination of urea". J. Clin. Path., 13 : 156159.

- Gopa, B.; Bhatt, J. and Hemavathi, G.K. ( 2012 ) : "A comparative clinical study of hypolipidemic efficacy of Amla (Emblica officinalis) with 3-hydroxy-3-methylglutaryl-coenzyme-A reductase inhibitor simvastatin". Date of Submission, 44 ( 2 ) : 238 - 242.

- Fossati, P. and prencipe, L. ( 1982 ) : Determination of triglyceride. Clin. Chem., $28: 2077$.

- Friedwald, W.T. and Levy, R.I. ( 1972 ) : "Estimation of the concentration of low density lipoprotein separated by three different methods". Clin. chem., $18: 499$ - 50.

- Hannan, J.M.A.; Marenah, L.; Ali, L.; Rokeya, B.; Flatt, P.R. and Abdel-Wahab, Y.H.A. (2006) : "Ocimum sanctum leaf extracts stimulate insulin secretion from perfused pancreas, isolated islets and clonal pancreatic $\beta$-cells". Made available online as an Accepted Preprint 19 January.

- Haslam, D.W. and James, W.P. ( 2005 ) : "Obesity". Lancet, 366 ( 9492 ): $1197-209$.

- Hegsted, D.M.; Mills, R.C.; Evehyen, C.A. and Hart, E.B. ( 1941 ) : "Salt mixture". J. Biol. Chem., $138: 459$.

- Hendawy, Basma M. ( 2012 ): Studies on Correcting Obesity Using Commercial Polyherbal Formulation. Ph.D. Thesis, Faculty of Home Economics, Minufiya University.

- Henery, R. J. (1974) : "Clinical Chemist : Principles and Technics". 2 nd Edition, Hagerstown ( MD ), Harcer, Row, P.882.

- Hicham, H.; Hana, Caid S.; Nour El - Houda, Bouanani; Mohammed, A. and Souliman, A. (2004) : Hypolipidemic activity of polyphenol-rich extracts from Ocimum basilicum in Triton WR-1339-induced 
hyperlipidemic miceLiver function Ocimum basilicum. Type: Journal Article, 108 (1) : $205-212$.

- IFCC ( 1983 ) : Methods for the measurement of catalytic concentration of enzymes, Part 5: IFCC, methods for alkaline phosphatase. J. Clin. Chem. Clin. Biochem., $21: 731-748$.

- Imaz, I.; Martinez - Cervell, C.; Garcia - Alvarez, E.E.; Sendra Gutierrez, J.M. and Gonzalez - Enriquez, J. ( 2008 ) : "Safety and effectiveness of the intragastric balloon for obesity. A meta - analysis". Obes. Surg., 18 ( 7 ): $814-6$.

- James, D.B.; Owolabi, O.A.; Owolabi.; Elebo, N.; Hassan, S. and Odemene, L. ( 2009 ) : "Glucose tolerance test and some biochemical effect of Phyllanthus amarus aquoeus extacts on normoglycemic albino rats". African Journal of Biotechnology, 20 April; 8 ( 8 ) : 1637-1642.

- Kim, H.J.; Yokozawa, T.; Kim, H.Y.; Tohda, C.; Rao, T.P. and Juneja, L.R. (2005): "Influence of amla ( Emblica officinalis ) Gaertn. on hypercholesterolemia and lipid peroxidation in cholesterol-fed rats". J. Nutr. Sci. Vitaminol., ( Tokyo ), 51 ( 6 ) : $413-8$.

- Krishnaveni, M. and Mirunalini, S. ( 2010 ) : "Therapeutic potential of ( Phyllanthus emblica "amla" ) the ayurvedic wonder". Journal of Basic and Clinical Physiology and Pharmacology, 21 ( 1 ) : 93 - 105.

- Kushner, R. (2007) : "Treatment of the Obese Patient ( Contemporary Endocrinology )". Totowa, NJ: Humana Press. p. 158.

- Larsen, K. ( 1972 ) : "Creatinine coloremitic kinetic method". J. of Clin. Chem., ( 41 ) : 209.

- Manjunatha, S.; Jaryal, A.K.; Bijlani, RL.; Sachdeva, U. and Gupta, S.K. (2001) : "Effect of Chyawanprash and vitamin C on glucose tolerance and lipoprotein profile". Indian J. Physiol. Pharmacol., 45 ( 1 ) : 71 - 9.

- Mohamed, Sham H.; Shihabudeen, D.; Hansi, P. and Kavitha, T. ( 2011 ) : Cinnamon extract inhibits $\alpha-$ glucosidase activity and dampens postprandial glucose excursion in diabetic rats. Nutrition \& Metabolism, $8: 46$.

- Nakabayashi A.; Kitagawa Y.; Suwa Y.; Akimoto K. et al., (1995): $\alpha$ Tocopherol Enhances the Hypocholeserolemic Action of Sesames in Rats. Internat. J. Vit.Nutr. Res., 65 (3):162-168. 
- Patel, JR.; Tripathi, P.; Sharma, V.;Chauhan, NS.;Dixit, VK. (2011) : "Phyllanthus amarus": Ethnomedicinal uses, Phytochemistry and Pharmacology, 138 ( 2 ) : $286-313$.

- Reeves, P. G.; Nielson, F. H. and Fahmy, G. C.(1993): "Reports of the American Institute of Nutrition, Adhoc Wiling Committee on reformulation of the AIN 93. Rodent Diet". J. Nutri., 123: 1939-1951.

- Subhadra, L.B.; Sundaresan, S .; Singaravelu, A.; Nandhabalan, S.K.; Badri, N.R.; Chandrakanth, K.; Anil, D.R.; Yogendra, S.; Konasubrahmanya, S.; Vinay, B.; Simi, S.; Ruchi,T.; Suchitra, S. and Suchita, S. ( 2009 ) : Cinnamic acid, from the bark of Cinnamomum cassia, regulates glucose transport via activation of GLUT4 on L6 myotubes in a phosphatidylinositol 3-kinase-independent manner. Journal of diabetes.

- Umar, A.; Imam, G.; Yimin, W.; Kerim, P.; Tohti, T.; Berké, B. and Moore, N. ( 2010 ) : Antihypertensive effects of Ocimum basilicum L. $(\mathrm{OBL})$ on blood pressure in renovascular hypertensive rats. Hypertension Research, Jul; 33 ( 7 ) : 727 - 30.

- WHO (2000): Tobacco Kills, Don't Be Duped, It Shouldn't Be Advertized, Glomorized or Subsidized : Media Kit for World NoTobacco Day 2000 , Geneva.

- Yokozawa, T.; Young, H.; Kim, Y.; Kim, H. Ju.; Tanaka, T.; Hidetoshi, T.; Sugino, H.; Tsutomu, S.; Okubo, T.; Djong, O.; Chi Chu, D. and Juneja, L. ( 2007 ) : "Amla (Emblica officinalis Gaertn.) attenuates agerelated renal dysfunction by oxidative stress". J. Agric. Food Chem., 55 ( 19 ) : $7744-7752$.

- Yound, D.S. ( 1975 ) : "Determination of GOT". Clin. Chem., 22 ( 5 ) : 1 $-21$. 


\section{تأثير بهض النباتات والبذور عند استخداهها لففض السيمنة في ذكور الفئران البيضاء}

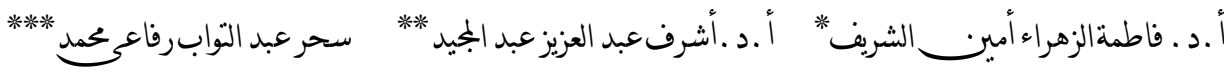

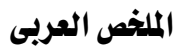

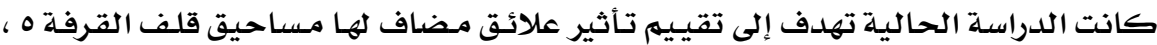

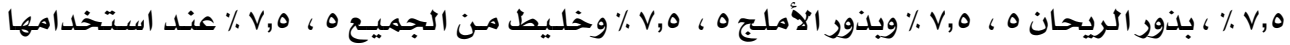

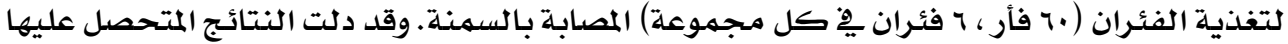

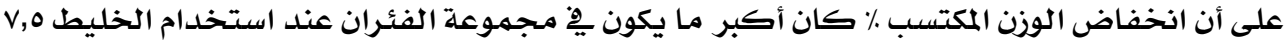

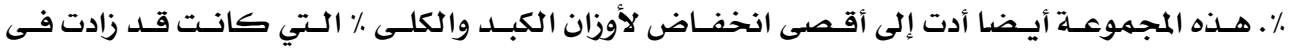

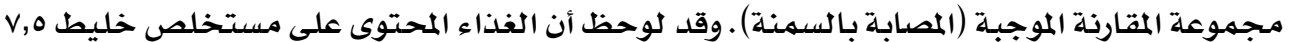
٪ نباتات وبذور كان أفضل معاملـة لخفض مستوى جلوكوز السيرم مـع إحـداث تحسن شـديد لصور

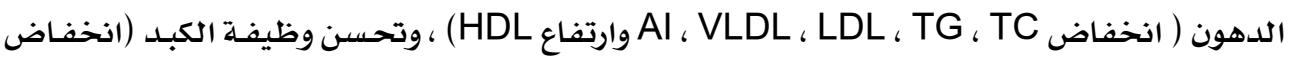

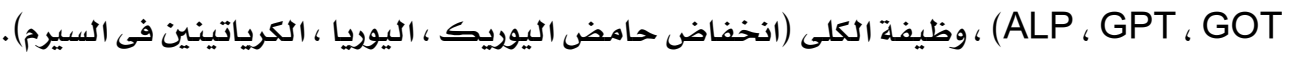
رد على ذلك أن استخدام المجموعة المذكورة أدى إلى تصحيح واضح فى التغيرات الهستوباثولوجية. الكلمات المفتاحية:

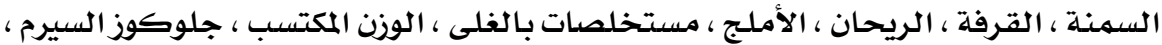

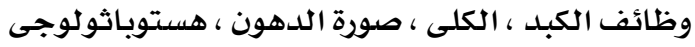

